\title{
NILAI EKONOMI HASIL HUTAN NON KAYU DAN KONTRIBUSINYA TERHADAP PENDAPATAN RUMAH TANGGA (Studi Kasus Pada Dua Desa Sekitar Taman Wisata Sibolangit)
}

\author{
Ridwanti Batubara dan Oding Affandi \\ Program Studi Kehutanan Fakultas Kehutanan Universitas Sumatera Utara \\ Jl. Tridharma Ujung No.1 Kampus USU Medan 20155 \\ Email: ridwantibb@yahoo.com,
}

\begin{abstract}
People around the Park Tour (PT) Sibolangit develop many HHNK on land owned. Therefore, this study aims to: (1) find out the types of NTFPs most used by the community, (2) to know the value of HHNK products, (3) to know the contribution of HHNK to the income of the community. This research was conducted by survey method and conducted in two selected villages namely Sembahe Village and Bengkurung Village, Sibolangit Sub-district, Deli Serdang Regency. Communities in both research sites developed and utilized HHNK such as pecan, petai, duku, durian, jengkol, mangosteen, areca nut, nira (aren) water, ginger, temulawak, and others. Most of these HHNK are commercial (sold). HHNK that has the greatest potential of water sap. The economic value of HHNK in Sembahe village reaches Rp. 967.529 .300 / year or accounted for about $57.28 \%$ of total family income. While the economic value of HHNK in Bengkurung village reached Rp 509,180,000 / year or accounted for about $65.57 \%$ of total household income.
\end{abstract}

Keywords: HHNK, economic value, income.

\section{PENDAHULUAN}

Keberadaan hutan memiliki arti penting sebagai sumberdaya hayati yang dimanfaatkan baik secara langsung maupun tidak langsung guna memenuhi hajat hidup orang banyak. Oleh sebab itu hutan mendapat perhatian khusus terutama dalam pengelolaan dan pemanfaatannya sehingga diharapkan dapat dinikmati seoptimal mungkin dengan tetap mengacu pada pemanfaatan yang lestari. Pemanfaatan hutan yang kurang bijaksana dengan mengabaikan aspek- aspek pemanfaatan hutan yang berkesinambungan dikhawatirkan dapat mengurangi fungsi hutan.

Hasil Hutan Non Kayu (HHNK) semula disebut Hasil Hutan Ikutan merupakan hasil hutan yang bukan kayu berasal dari bagian pohon atau tumbuhtumbuhan yang memiliki sifat khusus yang dapat menjadi suatu barang yang diperlukan oleh masyarakat, dijual sebagai komoditi ekspor atau sebagai bahan baku untuk suatu industri. HHNK pada umumnya merupakan hasil sampingan dari sebuah pohon, misalnya 
getah, daun, kulit, buah dan lain-lain atau berupa tumbuhan-tumbuhan yang memiliki sifat khusus seperti rotan, bambu dan lain-lain.

Taman Wisata (TW) Sibolangit merupakan salah satu taman wisata di Propinsi Sumatera Utara yang kaya akan berbagai jenis tumbuh-tumbuhan (flora). Jenis flora tersebut bukan hanya sekedar untuk koleksi, melainkan juga memberikan kontribusi yang sangat penting bagi keperluan ilmu pengetahuan dan pendidikan (sebagai laboratorium alam) serta pengembangan pariwisata (rekreasi). Oleh karenanya pada tahun 1980 berdasarkan Surat Keputusan Menteri Pertanian No. 636/Kpts/Um/9/1980 ditetapkan menjadi kawasan Taman Wisata Sibolangit (yang sebelumnya sebagai Cagar Alam Sibolangit) seluas lebih kurang 24,85 $\mathrm{Ha}$ (Balai Konservasi Sumberdaya Alam I Medan, 1999). Selain untuk kepentingan pendidikan dan pariwisata TW Sibolangit juga menjadi sumber penghidupan masyarakat yang bernaung di sekitarnya yaitu dengan memanfaatkan (mengambil) hasil hutan non kayu yang disekitar kawasan tersebut.

\section{Perumusan Masalah}

Taman Wisata (TW) Sibolangit sebagai kawasan konservasi memiliki keragaman flora dan fauna. Dalam konsep konservasi yang diinginkan adalah pelestraian dan pemanfaatan. Selama ini pengelolaan hutan Sibolangit telah memberikan manfaat yang cukup besar khususnya dalam pengaturan tata air (Balai Konservasi Sumberdaya Alam I Medan, 1999). Sedangkan manfaat bagi masyarakat sekitar adalah memanfaatkan hasil sampingan pohon misal getah, daun, kulit, buah dan lainlain atau tumbuhan yang memiliki sifat khusus yang dapat dimanfaatkan atau lebih dikenal dengan memanfaatkan hasil hutan non kayu (HHNK). HHNK yang sudah diteliti dari kawasan Tahura adalah tumbuhan obat dan aromatika.

Batubara dan Afifuddin (2010) menyatakan jenis tumbuhan obat dan aromatika yang dimanfaatkan oleh masyarakat sekitar Tahura Bukit Barisan ada 133 jenis. Bagaimana dengan HHNK yang lain? Pada dasarnya tanaman HHNK ini dapat membantu pendapatan masyarakat sekitar hutan.

Berdasarkan hal di atas maka perlu dilakukan kajian untuk mengetahui jenis-jenis HHNK yang biasa dimanfaatkan oleh masyarakat desa sekitar TW Sibolangit, mengetahui 
potensi dan sistem pemasaran HHNK yang dimanfaatkan masyarakat sekitar hutan TW Sibolangit. Sehingga penelitian yang akan dilakukan adalah Potensi dan Nilai Ekonomi HHNK yang dimanfaatkan masyarakat sekita TW Sibolangit.

\section{METODE PENELITIAN}

\section{A. Lokasi Penelitian}

Penelitian dilaksanakan di dua Desa sekitar TW Sibolangit. Desa yang dipilih adalah desa yang masih ditemukan memanfaatkan HHNK dari kawasan TW Sibolangit.

\section{B. Alat dan Bahan}

Adapun alat yang digunakan dalam penelitian ini adalah kamera, alat tulis dan kalkulator. Bahan yang digunakan dalam penelitian ini adalah kuesioner, Peta Wilayah Kabupaten dan dokumen lain yang berkaitan dengan lokasi studi.

\section{Metode Pengumpulan Data}

Penelitian bersifat eksploratif, pengumpulan data dilakukan dengan mengkombinasikan Metode Telaahan Dokumentasi (Documentation Study) dari berbagai sumber data sekunder dan Metode Langsung (Direct Methods) yaitu pengumpulan data primer di lapangan dengan teknik wawancara (dengan dan tanpa kuesioner) dan observasi lapangan. Pengumpulan data langsung di lapangan, khususnya di daerah terpilih sebagai lokasi kajian dilakukan dengan maksud pengambilan data langsung dan mengecek data sekunder di lapangan

Data primer yang dikumpulkan antara lain adalah jenis dan jumlah HHNK (manfaat tangible), data sosial ekonomi, frekuensi pengambilan, lama dan waktu pengambilan, biaya pengambilan dan bentuk pengelolaan dan hasil pemasaran. Sedangkan data sekunder yang dikumpulkan antara lain adalah: kondisi umum lokasi penelitian atau data umum yang ada pada instansi pemerintahan desa dan kecamatan.

\section{Analisis Data}

Data yang diperoleh dari hasil pengamatan di lapangan baik melalui wawancara maupun kuesioner kemudian dianalisis secara kuantitatif. Nilai barang hasil hutan untuk setiap jenis per tahun yang diperoleh masyarakat dihitung yaitu: harga barang hasil hutan (manfaat tangible) yang diperoleh dianalisis dengan pendekatan harga pasar, nilai rata-rata jumlah barang yang diambil per responden per jenis, total pengambilan per unit barang per tahun, nilai ekonomi barang hasil 
hutan per jenis barang per tahun, persentase nilai ekonomi persentase nilai ekonomi, pendapatan total, pendapatan dari dalam hutan dan luar hutan, dan kontribusi pemanfaatan hasil hutan.

\section{HASIL DAN PEMBAHASAN}

A. Jenis-jenis Hasil Hutan Non Kayu (HHNK) yang Berpotensi Secara Ekonomi dan Dimanfaatkan Masyarakat

HHNK yang dimanfaatkan oleh masyarakat pada dua desa penelitian merupakan tanaman warisan turun temurun dari nenek moyang mereka. Hasil hutan yang dimanfaatkan oleh masyarakat sangat beragam ada yang bertujuan untuk memenuhi kebutuhan mereka sendiri (kebutuhan sehari-hari) dan ada juga yang dijual untuk menambah pendapatan rumah tangga mereka. Pemungutan hasil hutan non kayu pada umumnya merupakan kegiatan tradisional dari masyarakat yang berada disekitar hutan, bahkan di beberapa tempat, kegiatan pemungutan hasil hutan non kayu merupakan kegiatan utama sebagai sumber kehidupan masyarakat sehari-hari (Dephut, 2002). Jenis hasil hutan yang dimanfaatkan di Desa Sembahe dan Desa Bengkurung dapat dilihat pada Tabel 1.

Tabel 1. Jenis HHNK yang dimanfaatkan oleh masyarakat Desa Sembahe dan Desa Bengkurung

\begin{tabular}{llcccc}
\hline \multirow{2}{*}{ No Nama } & & \multicolumn{5}{c}{ Responden yang Memanfaatkan (orang) } \\
\cline { 3 - 6 } & & $\begin{array}{c}\text { Desa } \\
\text { Sembahe }\end{array}$ & $\%$ & $\begin{array}{c}\text { Desa } \\
\text { Bengkurung }\end{array}$ & $\%$ \\
\hline 1 & Kemiri (Aleurites moluccana) & 10 & 33,33 & 19 & 63,33 \\
2 & Petai (Parkia speciosa) & 18 & 60,00 & - & - \\
3 & Durian (Durio zibethinus) & 18 & 60,00 & 8 & 26,67 \\
4 & Jengkol (Pithecollobium jiringa) & 10 & 33,33 & - & - \\
5 & Kunyit (Curcuma domestica) & 6 & 20,00 & - & - \\
6 & Air Aren/air nira (Arenga pinnata) & 6 & 20,00 & 13 & 43,33 \\
7 & Jahe (Zingeber officinale) & 5 & 16,66 & - & - \\
8 & Pinang (Areca catechu) & 13 & 43,33 & 15 & 50,00 \\
9 & Manggis (Garcinia mangostana) & 16 & 53,33 & 4 & 13,33 \\
10 & Temulawak(Curcuma xanthorrhiza) & 3 & 10,00 & - & - \\
11 & Asam Gelugur (Garcinia atroviridis) & 13 & 43,33 & - & - \\
12 & Rumbia (Metroxylon sp) & 10 & 33,33 & - & - \\
13 & Patikala & 15 & 50,00 & - & - \\
14 & Langsat (Lansium domesticum) & 13 & 43,33 & - & - \\
15 & Rambe & - & - & 5 & 16,67 \\
16 & Duku (Lansium domesticum) & 6 & 20 & 6 & 20,00 \\
\hline
\end{tabular}


Berdasarkan Tabel 1, ada 15 jenis HHNK yang berpotensi (memiliki nilai jual) dari Desa Sembahe dan 8 jenis dari desa Bengkurung. Ada 7 jenis HHNK yang sama dihasilkan dari 2 desa tersebut yaitu kemiri, durian, air nira, pinang, manggis dan duku. Jenis yang tidak sama antara 2 desa tersebut adalah jenis Rambe yang tidak dihasilkan di Desa Sembahe. Jenis HHNK dari Desa Sembahe lebih beragam dibandingkan dengan yang dari Desa Bengkurung, hal ini karena pada Desa Sembahe lebih dekat ke kota dan produk yang mereka hasilkan lebih cepat dan mudah penjualannya, penyebab lain adalah masyarakat Desa Sembahe lebih optimal dalam memanfaatkan lahan hutan yaitu dengan menanam jenis tanaman obat (kunyit, jahe dan temu lawak) pada areal yang kosong.

\section{B. Potensi dan Kategori Pemanfaatan HHNK Oleh Masyarakat}

HHNK yang dimanfaatkan oleh masyarakat dari dalam hutan dapat dikelompokkan menjadi dua kategori: (a) produktif, yaitu yang diperjualbelikan di pasar, dan (b) konsumtif, yaitu yang dikonsumsi sendiri dan tidak dijual (Primack, 1993 dalam Ngakan, dkk.,
2006). Tabel 2 memperlihatkan beberapa jenis HHNK yang diambil dan dimanfaatkan oleh masyarakat Desa Sembahe dan Desa Bengkurung.

Hasil penelitian ini menunjukkan bahwa sampai saat ini semua jenis HHNK yang yang dimanfaatkan oleh masyarakat di kedua desa merupakan sumber penghidupan yang dalam membantu perekonomian rumah tangga. Hal ini ditunjukkan dengan dijadikannya semua HHNK tersebut sebagai barang yang bersifat komersil (produktif).

Dari sisi potensi HHNK yang dimanfaatkan masyarakat, air aren (nira) merupakan hasil hutan yang paling potensial karena sering diambil oleh masyarakat Desa Sembahe dan Desa Bengkurung. Air aren dihasilkan dan diambil setiap harinya dari tanaman aren dengan frekuensi pengambilan dua kali dalam sehari. Berdasarkan hasil wawancara dengan masyarakat, tanaman aren yang tumbuh saat ini merupakan tanaman yang tumbuh secara alami yang dibantu oleh musang. Tanaman aren banyak tumbuh di ladang-ladang dan kebun masyarakat, di hutan, bahkan di pekarangan rumah. Tanaman aren biasanya tumbuh menyebar dan bercampur dengan tanaman keras lainnya. 
Tabel 2. Kategori Jenis HHNK yang Dimanfaatkan oleh Masyarakat Desa Sembahe dan Desa Bengkurung

\begin{tabular}{|c|c|c|c|c|}
\hline No. & $\begin{array}{c}\text { Jenis } \\
\text { Sumberdaya } \\
\text { havati }\end{array}$ & \multicolumn{2}{|c|}{ Kategori } & Keterangan \\
\hline 1 & $\begin{array}{l}\text { Kemiri } \\
\text { (Aleurites } \\
\text { moluccana) }\end{array}$ & \multicolumn{2}{|c|}{ Produktif } & $\begin{array}{l}\text { Diambil, } \\
\text { tidak } \\
\text { bermusim }\end{array}$ \\
\hline 2 & $\begin{array}{l}\text { Petai (Parkia } \\
\text { speciosa) }\end{array}$ & \multicolumn{2}{|c|}{ Produktif } & $\begin{array}{l}\text { Diambil, } \\
\text { tidak } \\
\text { bermusim }\end{array}$ \\
\hline 3 & $\begin{array}{l}\text { Durian (Durio } \\
\text { zibethinus) }\end{array}$ & \multicolumn{2}{|c|}{ Produktif } & $\begin{array}{l}\text { Diambil, } \\
\text { bermusim }\end{array}$ \\
\hline 4 & $\begin{array}{l}\text { Jengkol } \\
\text { (Pithecollobiu } \\
\text { m jiringa) }\end{array}$ & \multicolumn{2}{|c|}{ Produktif } & $\begin{array}{l}\text { Diambil, } \\
\text { tidak } \\
\text { bermusim }\end{array}$ \\
\hline 5 & $\begin{array}{l}\text { Kunyit } \\
\text { (Curcuma } \\
\text { domestica) }\end{array}$ & \multicolumn{2}{|c|}{ Produktif } & $\begin{array}{l}\text { Diambil, } \\
\text { tidak } \\
\text { bermusim }\end{array}$ \\
\hline 6 & $\begin{array}{l}\text { Air Aren/air } \\
\text { nira (Arenga } \\
\text { pinnata) }\end{array}$ & \multicolumn{2}{|c|}{ Produktif } & $\begin{array}{l}\text { Diambil, } \\
\text { tidak } \\
\text { bermusim }\end{array}$ \\
\hline 7 & $\begin{array}{l}\text { Jahe } \\
\text { (Zingeber } \\
\text { officinale) }\end{array}$ & \multicolumn{2}{|c|}{ Produktif } & $\begin{array}{l}\text { Diambil, } \\
\text { tidak } \\
\text { bermusim }\end{array}$ \\
\hline 8 & $\begin{array}{l}\text { Pinang } \\
\text { (Areca } \\
\text { catechu) }\end{array}$ & \multicolumn{2}{|c|}{ Produktif } & $\begin{array}{l}\text { Diambil, } \\
\text { tidak } \\
\text { bermusim }\end{array}$ \\
\hline 9 & $\begin{array}{l}\text { Manggis } \\
\text { (Garcinia } \\
\text { mangostana) }\end{array}$ & \multicolumn{2}{|c|}{ Produktif } & $\begin{array}{l}\text { Diambil, } \\
\text { tidak } \\
\text { bermusim }\end{array}$ \\
\hline 10 & \multicolumn{2}{|c|}{$\begin{array}{l}\text { Temulawak (Curc } \\
\text { uma xanthorrhiza) }\end{array}$} & $\begin{array}{l}\text { Prod } \\
\text { uktif }\end{array}$ & $\begin{array}{l}\text { Diambil, } \\
\text { tidak } \\
\text { bermusim }\end{array}$ \\
\hline 11 & $\begin{array}{l}\text { Asam Gelt } \\
\text { (Garcinia } \\
\text { atroviridis) }\end{array}$ & Gelugur & $\begin{array}{l}\text { Prod } \\
\text { uktif }\end{array}$ & $\begin{array}{l}\text { Diambil, } \\
\text { tidak } \\
\text { bermusim }\end{array}$ \\
\hline 12 & \multicolumn{2}{|c|}{$\begin{array}{l}\text { Rumbia } \\
\text { (Metroxylon sp) }\end{array}$} & $\begin{array}{l}\text { Prod } \\
\text { uktif }\end{array}$ & $\begin{array}{l}\text { Diambil, } \\
\text { tidak } \\
\text { bermusim }\end{array}$ \\
\hline 13 & \multicolumn{2}{|l|}{ Patikala } & $\begin{array}{l}\text { Prod } \\
\text { uktif }\end{array}$ & $\begin{array}{l}\text { Diambil, } \\
\text { bermusim }\end{array}$ \\
\hline 14 & \multirow{2}{*}{\multicolumn{2}{|c|}{$\begin{array}{l}\text { Langsat (Lans } \\
\text { domesticum) } \\
\text { Rambe } \\
\text { (Bacaurea } \\
\text { motleyana) }\end{array}$}} & $\begin{array}{l}\text { Prod } \\
\text { uktif }\end{array}$ & $\begin{array}{l}\text { Diambil, } \\
\text { bermusim }\end{array}$ \\
\hline 15 & & & $\begin{array}{l}\text { Prod } \\
\text { uktif }\end{array}$ & $\begin{array}{l}\text { Diambil, } \\
\text { bermusim }\end{array}$ \\
\hline 16 & \multicolumn{2}{|c|}{ domesticum) } & $\begin{array}{l}\text { Prod } \\
\text { uktif }\end{array}$ & $\begin{array}{l}\text { Diambil, } \\
\text { bermusim }\end{array}$ \\
\hline
\end{tabular}

Dalam budaya masyarakat Batak nira terbagi menjadi dua dua jenis sesuai dengan resepnya, yaitu yang manis dan yang pahit (mengandung alcohol, dan dikenal dengan tuak). Tuak merupakan hasil olahan dari nira, setelah nira dimasukkan ke dalam bak tuak sejenis kulit kayu yang disebut kayu raru supaya cocok rasanya dan alkoholnya. Raru inilah yang mengakibatkan peragian dan proses permentasi sehingga menghasilkan alkohol. Pada umumnya tuak ini berwarna keputih-putihan seperti air beras.

Nira yang rasanya manis atau dalam bahasa Batak Toba disebut tuak na tonggi (yang tidak mengandung alcohol) sering dipakai sebagai minuman pada acara-acara atau upacara adat di Etnik Batak. Tuak na tonggi biasanya disajikan sebagai minuman adat pada dua upacara adat resmi, yaitu (1) upacara manuan ompuompu dan (2) upacara manulangi. Dalam upacara manuan ompu-ompu, ketika orang yang sudah bercucu meninggal, ditanam beberapa jenis tanaman di atas tambak. Tambak pada aslinya merupakan kuburan dari tanah yang terlapis. Menurut aturan adat, air dan tuak harus dituangkan pada 
tanaman di atas tambak. Sedangkan dalam upacara manulangi, para keturunan dari seseorang nenek memberikan makanan secara resmi kepada orang tua tersebut yang sudah bercucu, dimana turunannya meminta restu, nasehat dan pembagian harta, disaksikan oleh pengetua-pengetua adat. Pada waktu memberikan makanan harus disajikan air minum serta tuak.

Selain dalam upacara adat, tuak (khusunya yang pahit) banyak dijual di kedai-kedai (lapo) dan menjadi minuman sehari-hari bagi kaum laki-laki etnik Batak. Di daerah Tapanuli secara umum, biasanya laki-laki yang menyelesaikan kerjanya berkumpul di kedai pada sore hari. Mereka berbincang-bincang, menyanyi, memain kartu, bercatur dan menonton televisi, sambil minum tuak. Pada umumnya seorang petani biasa minum tuak beberapa gelas sehari.

Permintaan produk-produk yang dihasilkan dari tanaman aren diprediksi akan selalu meningkat sejalan dengan perkembangan pembangunan yang ada. Oleh karena itu penanaman atau pembudidayaan tanaman aren mempunyai harapan atau prospek yang baik di masa datang.

\section{B. Nilai Ekonomi HHNK}

Nilai ekonomi HHNK diperoleh dari perkalian total pengambilan per jenis pertahun dengan harga hasil hutan perjenis. Berdasarkan penelitian yang sudah dilakukan kepada 60 orang responden dari masyarakat Desa Sembahe (30 orang) dan Desa Bengkurung (30 orang), diperoleh bahwa nilai ekonomi dari pemanfaatan hasil hutan bukan kayu yang ada di Desa Sembahe sebesar Rp. 967.529.300,-/tahun yang berasal dari HHNK seperti kemiri, petai, durian, jengkol, kunyit, air aren, jahe, pinang, manggis, temulawak, asam gelugur, daun rumbia, asam patikala, langsat, dan duku. Sedangkan nilai ekonomi dari pemanfaatan hasil hutan oleh masyarakat di Desa Bengkurung Kecamatan Sibolangit Kabupaten Deli Serdang sebesar Rp 542.030.000,- per tahun. Nilai ini diperoleh dari HHNK yang dimanfaatkan masyarakat seperti air nira, duku, durian, pinang, petai, kemiri, jahe dan rumbia seperti terlihat pada Tabel 3 dan Tabel 4. 
Tabel 3. Nilai Ekonomi HHNK yang Dimanfaatkan Masyarakat Desa Sembahe

\begin{tabular}{llcrrrr}
\hline No & Jenis HHNK & Satuan & \multicolumn{1}{c}{ TP } & $\begin{array}{c}\text { Harga } \\
\text { (Rp) }\end{array}$ & \multicolumn{1}{c}{ NE (Rp) } & \multicolumn{1}{c}{$\%$ NE } \\
\hline 1 & Kemiri & $\mathrm{kg}$ & 9180 & 5.500 & 50.490 .000 & $5,22 \%$ \\
2 & Petai & ikat & 4578 & 18.000 & 80.604 .000 & $8,33 \%$ \\
3 & Durian & buah & 21977 & 4.500 & 98.896 .500 & $10,22 \%$ \\
4 & Jengkol & $\mathrm{kg}$ & 1550 & 2.600 & 4.030 .000 & $0,42 \%$ \\
5 & Kunyit & $\mathrm{kg}$ & 230 & 5.000 & 1.150 .000 & $0,12 \%$ \\
6 & Air nira & liter & 22356 & 1.300 & 29.062 .800 & $3,00 \%$ \\
7 & Jahe & $\mathrm{kg}$ & 10500 & 14.000 & 147.000 .000 & $15,19 \%$ \\
8 & Pinang & $\mathrm{kg}$ & 14480 & 6.300 & 91.224 .000 & $9,43 \%$ \\
9 & Manggis & $\mathrm{kg}$ & 16605 & 18.000 & 298.890 .000 & $30,89 \%$ \\
10 & Temulawak & $\mathrm{kg}$ & 700 & 1.500 & 1.050 .000 & $0,11 \%$ \\
11 & Asam Gelugur & $\mathrm{kg}$ & 15130 & 1.200 & 18.156 .000 & $1,88 \%$ \\
12 & Rumbia & $\mathrm{kg}$ & 654 & 45.000 & 29.430 .000 & $3,04 \%$ \\
13 & Patikala & $\mathrm{kg}$ & 20880 & 5.000 & 59.400 .000 & $6,14 \%$ \\
14 & Langsat & $\mathrm{kg}$ & 9059 & 4.000 & 36.236 .000 & $3,75 \%$ \\
15 & Duku & $\mathrm{kg}$ & 3130 & 7.000 & 21.910 .000 & $2,26 \%$ \\
\hline & & & Jumlah & & 967.529 .300 & $100 \%$ \\
\hline
\end{tabular}

Keterangan:

TP $=$ Total Pengambil (Unit/tahun)

$\mathrm{NE}=$ Nilai Ekonomi

\section{Tabel 4. Nilai Ekonomi HHNK yang Dimanfaatkan Masyarakat di Desa} Bengkurung.

\begin{tabular}{rllrrrr}
\hline No & $\begin{array}{l}\text { Jenis } \\
\text { HHNK }\end{array}$ & Satuan & \multicolumn{1}{c}{ TP } & $\begin{array}{c}\text { Harga } \\
\text { (Rp) }\end{array}$ & \multicolumn{1}{c}{ NE (Rp) } & \% NE \\
\hline 1 & Air Nira & Liter & 17400 & 1750 & 390.600 .000 & $72.06 \%$ \\
2 & Duku & Kg & 1990 & 10000 & 19.900 .000 & $3.67 \%$ \\
3 & Durian & Biji & 2300 & 5000 & 11.500 .000 & $2.12 \%$ \\
4 & Manggis & Kg & 6410 & 10000 & 61.400 .000 & $11.33 \%$ \\
5 & Petai & lkat & 1750 & 15000 & 25.500 .000 & $4.70 \%$ \\
6 & Rambai & Kg & 9100 & 1500 & 13.650 .000 & $2.52 \%$ \\
7 & Kemiri & Kg & 2800 & 5000 & 13.800 .000 & $2.54 \%$ \\
8 & Pinang & $\mathrm{kg}$ & 710 & 8000 & 5.680 .000 & $1.05 \%$ \\
\hline & & & Total & 542.030 .000 & $100 \%$ \\
\hline
\end{tabular}

Keterangan:

TP $=$ Total Pengambil (Unit/tahun)

$\mathrm{NE}=$ Nilai Ekonomi

Nilai ekonomi HHNK yang ada di kedua lokasi penelitian memiliki nilai ekonomi yang cukup tinggi jika dibandingkan dengan nilai ekonomi di luar HHNK. Menurut Lidiawati (2003) nilai ekonomi adalah nilai barang dan 
jasa yang dapat diperjualbelikan, sehingga memberikan pendapatan. Dari konsep ekonomi bahwa kegunaan, kepuasan atau kesenangan yang diperoleh individu atau masyarakat tidak terbatas kepada barang dan jasa yang diperoleh melalui jual beli (transaksi) saja, tetapi semua barang dan jasa yang memberikan manfaat akan memberikan kesejahteraan bagi individu atau masyarakat. Bahwa barang dan jasa yang dapat diperjualbelikan menyangkut sifat barang dan jasa tersebut, yaitu memiliki kegunaan, bersifat langka dan kepemilikan yang jelas.

Berdasarkan studi di kedua lokasi penelitian (seperti terlihat pada Tabel 3 dan 4), diketahui bahwa HHNK yang mempunyai nilai ekonomi tertinggi adalah air nira dengan nilai sebesar $\mathrm{Rp}$ 419.662.000,- atau sekitar 27,80 \% dari total nilai ekonomi HHNK di kedua desa yaitu Rp 1,509,459,300,-. Besarnya nilai ekonomi air nira disebabkan air nira dikonsumsi setiap harinya oleh masyarakat sekitar TW Sibolangit atau masyakat lainnya di luar masyarakat sekitar TW Sibolangit. Masyarakt di sekitar TW Sibolangit yang sebagian besar etnis Batak, sudah terbiasa meminum air nira (tuak) di kedai setiap hari. Minuman tuak ini tidak hanya diminum di kedai saja, tetapi pada upacara adat. Di kedua lokasi desa penelitian apabila ada acara adat, baik itu pernikahan ataupun kematian biasanya keluarga yang memiliki acara adat tersebut sudah menyediakan beberapa jerigen besar tuak untuk diminum orang-orang yang membantu dalam acara tersebut sebagai penambah tenaga ataupun diminum pada acara adatnya itu sendiri.

HHNK lain yang mempunyai nilai ekonomi tinggi yaitu manggis dengan nilai ekonomi sekitar Rp. 360.290.000,atau sekitar $23,87 \%$ dari total nilai ekonomi HHNK di kedua desa. Manggis mempunyai nilai ekonomi yang tinggi karena jenis buah ini merupakan buah yang sering dijadikan oleh-oleh bagi pengunjung yang datang berekreasi ke TW Sibolangit. TW Sibolangit selain mempunyai daya tarik dalam hal pemandangan alam yang indah, ketenangan, kesejukan alam, dan mempunyai aneka koleksi (kebun) botaninya, juga merupakan tempat tepat untuk "berburu" buah-buahan segar. Di sepanjang jalan sekitar TW sibolangit akan terlihat kios-kios dagangan buahbuahan segar yang merupakan hasil bumi setempat, seperti: manggis, petai, rambutan, belimbing, apel, semangka 
jambu batu, dan lain-lain. Disamping itu Sibolangit juga terkenal dengan duriannya yang harum dan manis. Sehingga kurang lengkap rasanya perjalanan kalau tidak menikmati durian Sibolangit. Durian yang didagangkan dipinggir jalan ini dapat dinikmati di tempat ataupun dibawa pulang, tentunya dengan harga yang tidak terlalu mahal.

Adapun nilai ekonomi HHNK yang paling kecil adalah tanaman temulawak dan kunyit masing-masing sebesar Rp. 1.050.000,- dan 1.150.000,atau $0,069 \%$ dan $0,076 \%$. Tanaman temu lawak dan kunyit mempunyai nilai ekonomi yang paling rendah disebabkan karena tanaman ini tanaman baru yang baru mulai dibudidayakan oleh masyarakat, untuk menggantikan tanaman jahe. Jelas terlihat bahwa masyarakat berhasil dalam memanen berbagai jenis HHNK dalam ukuran yang sangat banyak. Hal itu membuktikan bahwa masyarakat mampu mengelola lahan dengan baik, sehingga produksi lahan tetap terjaga tanpa mengurangi nilai estetika, ekonomi, lingkungan dan ekologi dari kawasan hutan tersebut serta memberikan pengaruh besar terhadap kehidupan masyarakat yang berbatasan dengan hutan tersebut.

\section{Kontribusi HHNK Terhadap Pendapatan Masyarakat}

Masyarakat Desa Sembahe dan Desa Bengkurung memiliki beragam profesi, sehingga masyarakat tidak hanya mengandalkan pendapatan mereka hanya dari HHNK saja, namun mereka juga mengandalkan pendapatan dari pekerjaan lain misalnya seperti dari buruh tani, wirausaha, peternakan, agen, penganyam, PNS, pensiunan PNS, serta bidang pertanian (tanaman semusim) yang dapat dilihat pada Tabel 6 dan Tabel 7.

Berdasarkan hasil penelitian terlihat bahwa sumber pendapatan terbesar HHNK di Desa Sembahe adalah berasal dari pertanian yakni sebesar Rp. 330.466.000,-/tahun atau dengan persentase $45,80 \%$ dan sumber pendapatan terendah berasal dari peternakan sebesar Rp. 6.000.000,/tahun atau dengan persentase $0,83 \%$. Nilai ekonomi pendapatan dari luar pemanfaatan HHNK sebesar Rp. 721.506.000,-/tahun, bersumber dari pendapatan buruh tani, wirausaha, peternakan, agen, pengayam, pertanian, dan PNS. 
Tabel 5. Pendapatan Rumah Tangga Per Tahun di Luar Pemanfaatan HHNK di Desa Sembahe

\begin{tabular}{llcc}
\hline No & $\begin{array}{c}\text { Sumber } \\
\text { Pendapatan }\end{array}$ & $\begin{array}{c}\text { Jumlah } \\
(\mathrm{Rp})\end{array}$ & Presentase \\
\hline 1 & Buruh Tani & 75.600 .000 & $10,47 \%$ \\
2 & Wirausaha & 262.400 .000 & $36,36 \%$ \\
3 & Peternak & 6.000 .000 & $0,83 \%$ \\
4 & Agen & 16.000 .000 & $2,22 \%$ \\
5 & Pengayam & 7.040 .000 & 1,0 \\
6 & Pertanian & 330.466 .000 & $45,80 \%$ \\
7 & PNS & 24.000 .000 & $3,32 \%$ \\
\hline & Jumlah & $\mathbf{7 2 1 . 5 0 6 . 0 0 0}$ & $\mathbf{1 0 0} \%$ \\
\hline
\end{tabular}

Pendapatan rumah tangga yang diperoleh dari pemanfaatan hasil hutan bukan kayu oleh masyarakat Sembahe dapat dilihat pada Lampiran 2.6. Pendapatan bersih masyarakat dari HHNK diperoleh dari pengurangan antara pendapatan kotor hasil hutan bukan kayu dengan pengeluaran dalam pengolahan lahan. Pendapatan kotor dari pengolahan hasil hutan bukan kayu merupakan penjumlahan dari nilai ekonomi masing-masing hasil hutan bukan kayu yang dimanfaatkan oleh masing-masing responden.

Pengeluaran dari pengolahan HHNK, dikeluarkan oleh masing-masing responden. Pengeluaran ini dapat berupa upah tenaga kerja dan penyemprotan. Petani di desa Sembahe pada umumnya menggunakan tenaga kerja keluarga dalam pengolahan hasil hutan bukan kayu untuk mengurangi pengeluaran biaya terhadap tenaga kerja. Muljadi (1987) mengatakan semakin banyak anggota keluarga yang terlibat, maka akan mengurangi pengeluaran karena mendiskripsikan jumlah orang yang terlibat dalam kegiatan pengolahan lahan, apalagi jika lahannya luas.

Dengan

membandingkan pendapatan masyarakat dari HHNK (sebesar Rp. 910.568.300) dengan pendapatan masyarakat dari luar HHNK sebesar Rp. 721.506.000,/tahun, maka kita dapat melihat bahwa pendapatan yang terbesar diperoleh dari pendapatan HHBK dengan selisih sebesar Rp. 189.062.300. Rincian pendapatan ini dan besarnya kontribusi masing-masing pendapatan dapat dilihat pada Lampiran 2.7.

Total pendapatan masyarakat di Desa Sembahe dari HHNK dan dari luar HHNK dapat mencapai Rp. 1.632.047.300,-/tahun.

Hasil menunjukkan bahwa pendapatan masyarakat dari pemanfaatan HHNK mencapai sebesar Rp. 910.568.300,/tahun atau sekitar 55,79\%. Sementara pendapatan masyarakat dari luar hasil hutan bukan kayu hanya sebesar $\mathrm{Rp}$. 721.506.000,/tahun atau sekitar 44,21\%.

Sedangkan untuk Desa Bengkurung, berdasarkan hasil 
penelitian menunjukan bahwa total pendapatan masyarakat dari hasil memanfaatkan HHNK berupa jumlah keseluruhan dari nilai ekonomi yang dimanfaatkan mereka yaitu sebesar $R p$ 509.180 .000 ,-/tahunnya atau $65.57 \%$. Sedangkan dari luar pemanfaatan HHNK seperti pertanian, PNS, buruh tani, wirausaha dan peternakan memperoleh nilai manfaat ekonomi sebesar Rp 267.340.000,-/ tahun atau $34.43 \%$ (lihat Tabel 6). Data selengkapnya dapat dilihat pada Lampiran 3.5

Tabel 6. Pendapatan Rumah Tangga Per Tahun di Luar Pemanfaatan HHNK di Desa Bengkurung.

\begin{tabular}{clcc}
\hline No & $\begin{array}{c}\text { Sumber } \\
\text { Pendapatan }\end{array}$ & $\begin{array}{c}\text { Jumlah } \\
\text { (RP) }\end{array}$ & Presentase \\
\hline 1 & Wirausaha & 46.100 .000 & $18.05 \%$ \\
2 & Buruh tani & 39.000 .000 & $15.27 \%$ \\
3 & Peternakan & 5.500 .000 & $2.15 \%$ \\
4 & Pertanian & 140.440 .000 & $55.00 \%$ \\
5 & PNS & 24.300 .000 & $9.51 \%$ \\
\hline & Total & $\mathbf{2 5 5 . 3 4 0 . 0 0 0}$ & $\mathbf{1 0 0 \%}$ \\
\hline
\end{tabular}

Hasil ini menunjukkan bahwa pemanfaatan HHNK memberikan kontribusi yang nyata terhadap pendapatan masyarakat Desa Bengkurung. Hal ini terlihat jelas bahwa pendapatan dari HHNK lebih besar dibandingkan dengan hasil dari luar
HHNK seperti hasil pertanian, PNS, dagang, wirausaha, buruh tani dan agen. Dari total pendapatan rata-rata masyarakat sebesar Rp 776.520.000,per tahunnya. Dari hasil penelitian diperoleh bahwa pemanfaatan HHNK berdasarkan perhitungan nilai ekonominya diperoleh sebesar $\mathrm{Rp}$. 509.180 .000 ,- atau $65.57 \%$ dari total seluruh pendapatan masyarakat Desa Bengkurung.

Hasil penelitian dapat di tarik kesimpulan bahwa Desa Sembahe memiliki nilai ekonomi HHNK lebih besar dibandingkan dengan Desa Bengkurung di karenakan jumlah dan jenis hasil produksi yang di desa Bengkurung lebih sedikit, Masyarakat memiliki ketergantungan yang besar terhadap HHNK, hal ini dikarenakan HHNK terus berproduksi setiap tahunnya, dan apabila kebutuhan akan HHNK dari pihak konsumen meningkat maka harga jual juga cenderung meningkat.

Berdasarkan penelitian yang dilakukan Ngakan, dkk., (2006), HHNK merupakan sumberdaya alam yang paling bernilai dari hutan bagi masyarakat yang berada di sekitar hutan. Selain nilai ekonominya yang jauh lebih besar dari kayu, pemungutan HHNK tidak menyebabkan kerusakan 
hutan, sehingga tidak akan

pangan. mengakibatkan hilangnya fungsi-fungsi dan nilai jasa dari hutan baik dari segi ekologi serta hidrologinya. Ini artinya bahwa hutan sebagai sumberdaya yang bersifat multifungsi serta pemanfaatannya diarahkan untuk mewujudkan sebesar-besarnya untuk kemakmuran rakyat sudah mulai terwujud. Hal ini juga sesuai dengan penelitian penilaian nilai ekonomi pada masyarakat di sekitar Cagar Alam Dolok Sibual-buali yang dilakukan oleh Affandi dan Patana (2002), bahwa masyarakat yang berada di sekitar hutan menggantungkan hidupnya pada hasil hutan sehingga membawa dampak nilai ekonomi dari hasil hutan khususnya HHNK yang dimanfaatkan mereka adalah tergolong besar.

Besarnya sumber pendapatn masyarakat dari hutan, khususnya HHNK, menunjukkan bahwa sebagian besar masyarakat desa sekitar hutan sangat menggantungkan hidupnya terhadap keberadaan hutan. Nugraha dan Murtijo (2005) menyatakan bahwa hutan merupakan sumber pemenuhan kebutuhan masyarakat desa hutan, yang ditunjukkan dari ketergantungannya dalam hal pemenuhan kebutuhan tempat tinggal, lapangan pekerjaan, Masyarakat desa hutan membangun tempat tinggal di dalam dan sekitar hutan yang digunakan sebagai tempat bermukim dan melangsungkan regenerasi. Dengan demikian, hutan merupakan bagian hidup yang tidak terpisahkan dari kehidupan keseharian masyarakat desa hutan.

Sedangkan menurut Uluk, dkk., (2001) dalam penelitiannya terhadap tingkat ketergantungan masyarakat dayak terhadap hutan di sekitar Taman Nasional Kayan Mentarang menunjukan bahwa masyarakat Dayak di sekitar TN Kayan Mentarang sangat tergantung pada berbagai jenis hasil hutan. Berdasarkan penelitian mereka tercatat sebanyak 139 sampai 214 jenis hasil hutan yang dimanfaatkan untuk berbagai kepentingan dalam waktu satu tahun, antara lain sebagai sumber makanan, obat, bahan bangunan, sumber penghasilan uang tunai, upacara dan kebudayaan. Dengan tingginya kontribusi pendapatan masyarakat dari HHNK diharapkan dapat menekan penurunan fungsi hutan akibat pemanfaatan hasil hutan berupa kayu yang kurang mempertimbangkan aspek-aspek pemanfaatan lestari. 
KESIMPULAN

Jenis-jenis hasil hutan yang dimanfaatkan masyarakat di Desa Sembahe dan Bengkurung adalah kemiri, petai, durian, jengkol, kunyit, air nira, jahe, pinang, manggis, temulawak, asam gelugur, rumbia, patikala, langsat, rambe dan, duku. Nilai ekonomi HHNK di Desa Sembahe mencapai Rp. 967.529.300/tahun atau menyumbang sekitar 57,28\% terhadap pendapatan total keluarga. Sedangkan nilai ekonomi HHNK di desa Bengkurung mencapai Rp 509.180.000/tahun atau menyumbang sekitar $65.57 \%$ terhadap total pendapatan rumah tangga.

\section{DAFTAR PUSTAKA}

Affandi, O. dan Patana, P., 2002. Penelitian Perhitungan Nilai Ekonomi Pemanfaatan Hasil Hutan NonMarketable oleh Masyarakat Desa Sekitar Hutan. USU, Medan.

Aliadi,A. dan Djatmiko, A., 1998. Hasil Hutan Non Kayu Ekstraktif Di Desa Sungai Telang Rantau Pandan, Jambi.

Andayani, W. 2007. Jurnal Akta Agrosia (Vol. 10 No 1 Tahun 2007). Analisis Efisiensi Pemasaran Kacang Mete (Cashew Nuts) di Kabupaten Wonogiri. Jurusan Manajemen Hutan Kabupaten Kehutanan UGM, Yogyakarta.

Balai Konservasi Sumberdaya Alam I Medan. 1999. Informasi Kawasan
Konservasi Propinsi Sumatera Utara. Bali Scan dan Percetakan. Medan

BPDAS Jenebrang, 2010. Hasil Hutan Bukan Kayu (HHBK). Walanae.

Departemen Kehutanan dan Perkebunan. 1999. Undang-Undang No. 41 tahun 1999 Tentang Kehutanan.

Djajapertjunda., S dan Sumardjani. 2001. Hasil Hutan Non Kayu. Makalah untuk Kongres Kehutanan III. Jakarta.

Lidiawati, I. 2003. Penilaian Ekonomi Kerusakan Hutan dan Lahan Akibat Kebakaran. Institute Pertanian Bogor. Bogor.

Ngakan, P.O., H. Komarudin, A. Achmad, Wahyudi, dan A. Tako. 2006. Ketergantungan, Persepsi dan Partisipasi Masyarakat terhadap Sumberdaya Hayati Hutan. Studi Kasus di Dusun Pampli Kabupaten Luwu Utara, Sulawesi Selatan. 2006 - Center for International Forestry Research (CIFOR). Bogor

Suparmoko, M dan Maria Ratnaningsih. 2000. Ekonomika Lingkungan Edisi Pertama BPFE. Yokyakarta 